\title{
Population parameters of the yellow-edged lyretail (Variola louti, Forsskål, 1775) in Sibolga Waters
}

\author{
Ignatius Tri Hargiyatno ${ }^{1, *}$, Ria Faizah $1^{1}$ \\ ${ }^{1}$ Center for Fisheries Research, Indonesia, Ancol Jakarta
}

\begin{abstract}
The grouper is one of the coral fishery commodities with high economic value. One of the members of the Serranidae family is the yellow-edged lyretail (Variola louti). In Sibolga waters, this fish was caught by traps and handline. The exploitation of yellow-edged lyretail in Sibolga waters was carried out continuously. Therefore, it was necessary to take good management measures to maintain the sustainability of this fish. This study was conducted in Sibolga from April-December 2016. This study aims to get information about population parameters, size distribution, and growth patterns of the fish in Sibolga waters. The size distribution of the yellow-edged lyretail caught was $24-41 \mathrm{~cm}$, with an average length of $31.57 \mathrm{~cm}$. The weight of the yellow-edged lyretail caught ranged from $200-680 \mathrm{~g}$. The mean weight was $395.53 \mathrm{~g}$. The growth pattern of the yellow-edged lyretail is negative allometric. The growth equation for a yellow-edged lyretail was $\mathrm{Lt}=48.55\left(1-\mathrm{e}^{-0.1(\mathrm{t}-0.7806)}\right)$. The value of length at first captured $(\mathrm{Lc})=31,99 \mathrm{~cm}$. Natural mortality $(\mathrm{M})=$ $0.42 /$ year, fishing mortality $(\mathrm{F})=0.50$ year. The exploitation rate $=$ $0.55 /$ year, it means the exploitation rate of the yellow-edged lyretail in Sibolga waters slightly exceeds the optimum
\end{abstract}

\section{Introduction}

Grouper has many species and belongs to reef fish resources, and is a prime commodity with high economic value. Grouper in Indonesia consists of various species, including humpback grouper, brown marble grouper, leopard grouper, giant grouper, and others. Grouper, included in the sub-family Epinephelinae, consists of 161 species belonging to 15 genera [1]. [2] stated that the grouper species are scattered in tropical and subtropical waters. Most of them (110 species) were found in Indo Pacific waters.

Many groupers are very important commodities as they have a very high economic value, which may reach US\$50/kg in Hong Kong [1]. As primary predators, groupers are carnivorous fish within the food chain system of coral reef ecosystems. The grouper has a long-life span of several decades, and the gonads mature to an advanced age approaching its age. Groupers typically belong to the protogynous hermaphrodite group; young fish are female and, after adulthood, transform into males [3]. The yellow-edged lyretail (Variola

\footnotetext{
* Corresponding author: igna.prpt@gmail.com
} 
louti) belongs to the family Serranidae. [4] It is reported that yellow-edged lyretail is a species associated with coral reefs; it lives at a depth of 3-240 m, usually less than $15 \mathrm{~m}$, and in clean water.

Sibolga waters, North Sumatera, is a part of the Indian Ocean West Sumatera Waters (FMA 572). [5] stated that Sibolga is one of the coastal areas located on the west coast of Sumatra and has become one of the fisheries productions centers in this region. It can be seen with the establishment of the Fishing Port of Nusantara or Pelabuhan Perikanan Nusantara (PPN) by the Ministry of Maritime Affairs and Fisheries. Fishing activities, especially capture fisheries in the city of Sibolga very high include grouper. In 2018, there were up to 31,155.84 tonnes of fish caught in Sibolga by the number of fishermen 7,595 people [6]

Grouper fisheries in Sibolga is a small-scale fishery. The Sibolga grouper was caught by using handline and traps. Grouper catches with handlines $15 \%$ of the total catch, included yellow-edged lyretail. Information on the biology and population parameters of yelloweyed catfish in Sibolga waters is still limited. Therefore, research related to this issue is necessary to ensure that good management measures can be taken to conserve this fish in this area. This study aims to obtain information about population parameters, size distribution, and growth patterns of yellow-eyed catfish in Sibolga waters.

\section{Materials and methods}

\subsection{Data collection}

Data and information were collected from April to December 2016 in the Pelabuhan Perikanan Nusantara (PPN) Sibolga. Total samples were 235 individuals recorded from handline fisheries. The total length and weight were collected for analysis of this study.

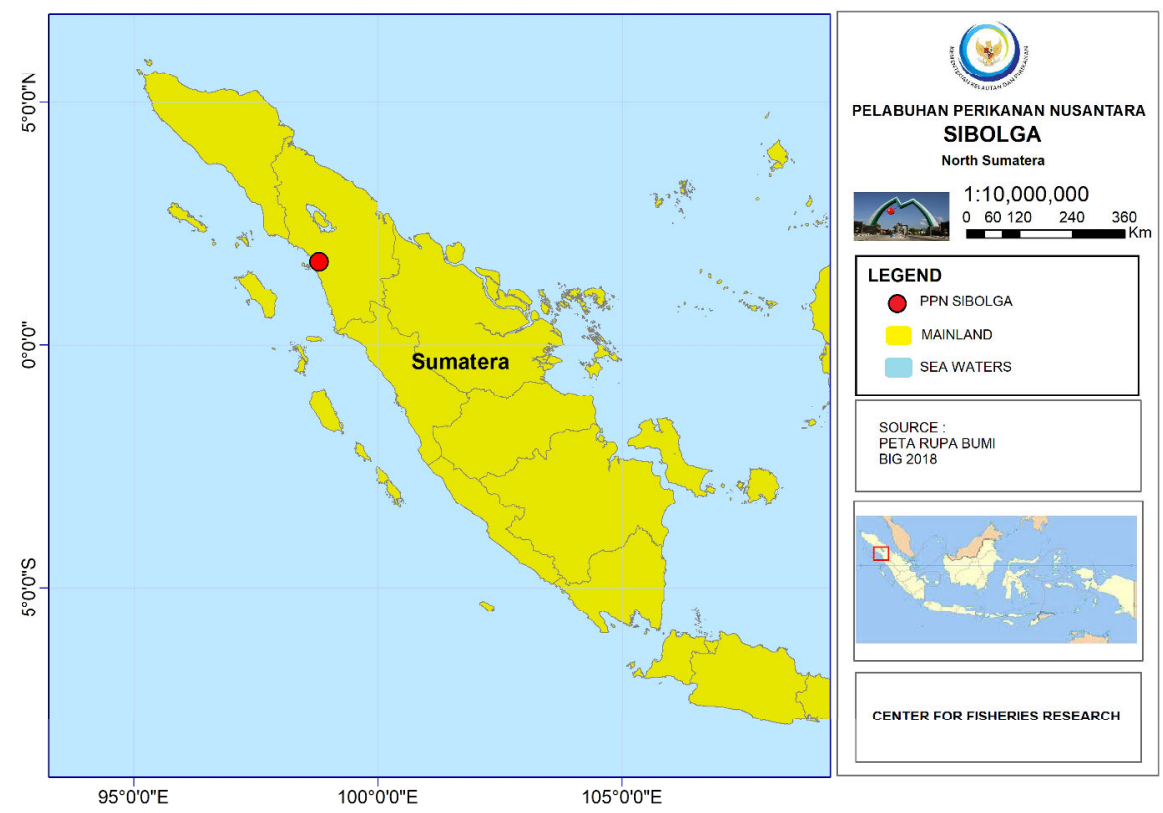

Fig. 1. Sampling location in Sibolga. 


\subsection{Data analysis}

Population parameters were observed, including growth, mortality, and exploitation rates, length at first capture. Growth parameters, length asymptotic $(\mathrm{L} \infty)$, i.e., the maximum length of fish theoretically, the growth coefficient $(\mathrm{K})$ allegedly using the ELEFAN I method in FISHAT II software [7]), and age theoretical (to) is estimated by an empirical equation [8] :

$$
\mathrm{Lt}=\mathrm{L}_{\infty} *\left(1-\mathrm{e}^{-\mathrm{k}(\mathrm{t}-\mathrm{to})}\right)
$$

to was calculated using the formula [9]

$$
\log \left(-\mathrm{t}_{0}\right)=-0.392-0.275 * \log \mathrm{L} \infty-1.038 * \log \mathrm{K}
$$

Total mortality $(Z)$ estimation was carried out with the catch conversion curve method with Length (Length converted catch curve) [8]. Fishing mortality (F) and exploitation rate (E) are calculated by formula [8]):

$$
\begin{aligned}
& \mathrm{Z}=\mathrm{M}+\mathrm{F} \\
& \mathrm{E}=\mathrm{F} / \mathrm{Z}
\end{aligned}
$$

The natural mortality (M) was calculated using formula by [10]:

$$
\log \mathrm{M}=-0.0066-0.279 \log \mathrm{L} \infty+0.6543 \log \mathrm{K}+0.4634 \log \mathrm{T}
$$

Where $\mathrm{T}\left({ }^{\circ} \mathrm{C}\right)=$ the annual mean water temperature.

Analysis of the length-weight relationship using equations

$$
\mathrm{W}=\mathrm{aL}^{\mathrm{b}}
$$

where: $\mathrm{W}=$ the weight, $\mathrm{a}=$ constant, $\mathrm{L}=$ the length, and $\mathrm{b}$ is value exponential between $2-5$

\section{Results and discussion}

\subsection{Length distribution}

During the study, 235 individuals of the yellow-edged lyretail (Variola louti) were landed at Sibolga. The yellow-edged lyretail (Variola louti) distribution is between 24 and $41 \mathrm{~cm}$ TL with an average size of $31.57 \mathrm{~cm}$ (Fig. 2). This range size was larger than reported by Wahbeh [11] that the range size was between $15.5-39.5 \mathrm{~cm}$. The weight of the fish caught ranged from 200-680 g, with an average weight of $395.53 \mathrm{~g}$. 


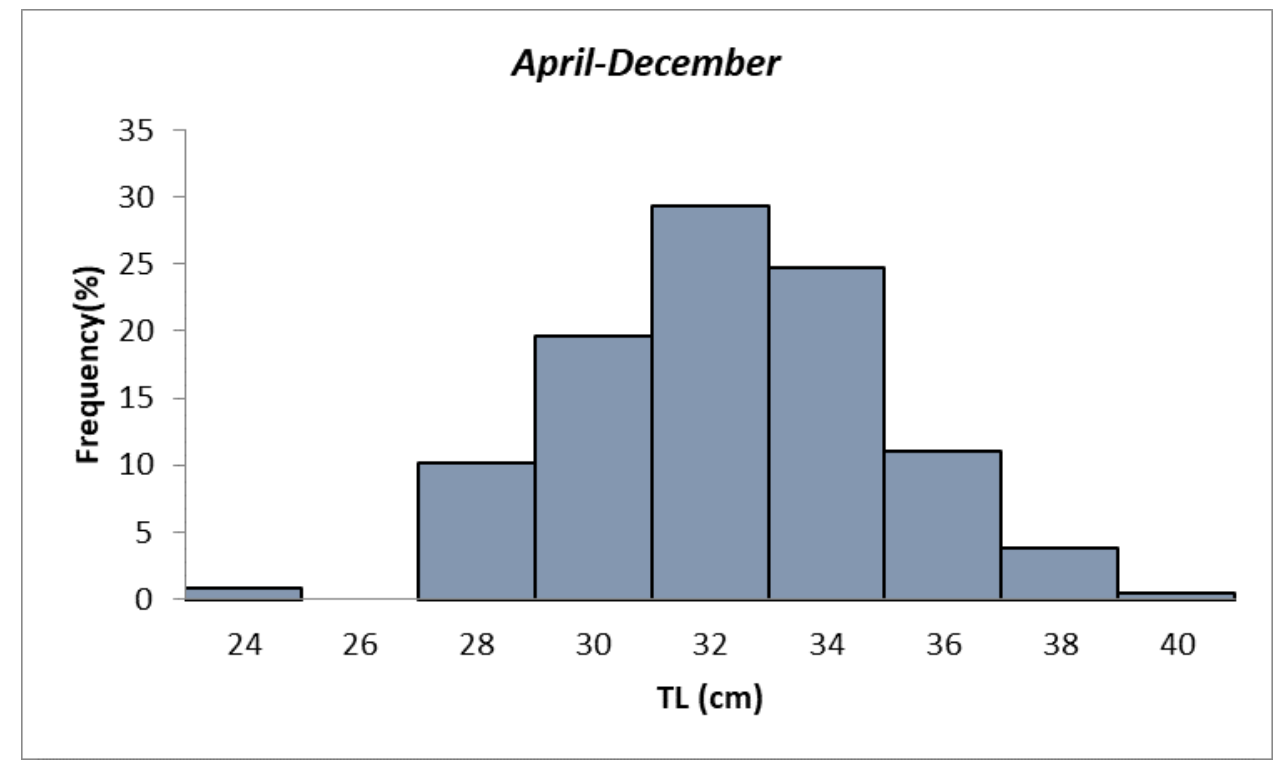

Fig. 2. Size distribution of the yellow-edged lyretail (Variola louti)

\subsection{Relationship of length and weight}

The length-weight relationship of $V$. variola was $\mathrm{W}=0.1167 \times \mathrm{L}^{2.3505}$. with $\mathrm{r}=0.8671$. The $\mathrm{b}$ value was lower than $3(b<3)$, which means the growth pattern was negative allometric. The $b$ value in this present study was smaller than from Guam, which was $b=3$.[12]. In general, the range of $b$ values was 2.5-3.5 [13]. [14] stated that the value of $b$ is influenced by physiological growth conditions such as gonadal maturity level or food. [15], [16] added that $b$ value was influenced by the condition of biology and environment, geographical, temporal, and sampling factor. [17] suggested that an allometric growth may be related to the lack of a suitable food supply for larger fish.

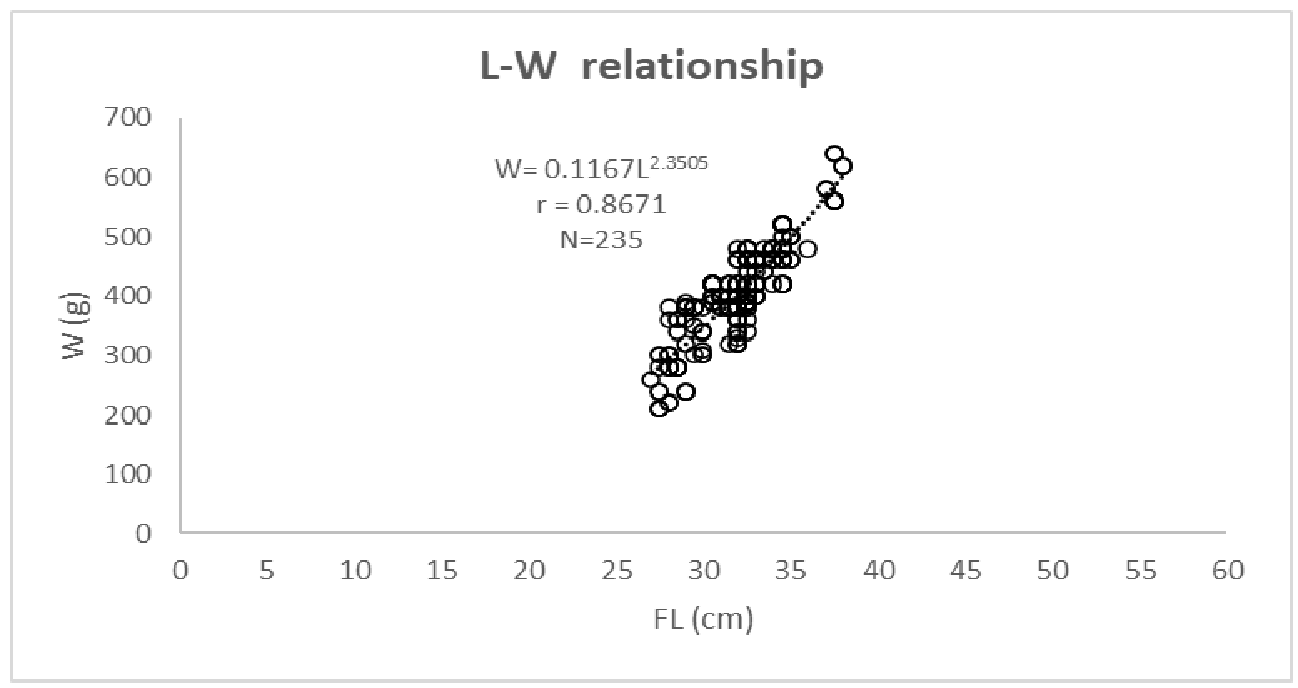

Fig. 3. Length-weight relationship of the yellow-edged lyretail (Variola louti) 


\subsection{Growth parameter $\left(L \infty, K, t_{0}\right)$}

Variola louti has growth equation is $\mathrm{Lt}=48.55\left(1-\mathrm{e}^{-0.1(\mathrm{t}-0.7806)}\right)$ which was asymptotic length $(\mathrm{L} \infty)=48.55 \mathrm{~cm}$ TL, the growth rate $(\mathrm{k})=0.13 /$ year, and to $=-0.78$ year. The $\mathrm{L} \infty$ and $\mathrm{k}$ value in present research were smaller than in Aldabra Atoll, Seychelles and in the gulf of Acaba which was the $\mathrm{L} \infty=51 \mathrm{~cm}, \mathrm{k}=0.48[16]$ and $\mathrm{L} \infty=54.6-65.7 \mathrm{~cm}, \mathrm{k}=0-1$ 0.102 per year [11].

[19] stated that the difference in asymptotic length was caused by fishing gear selectivity, aquatic environment, habitat differences, and genetic variation. The difference in growth coefficient $(\mathrm{K})$ was a factor in asymptotic length [20]. [21] argued that geographically, relative differences in local habitat quality, such as food availability, space, predator presence, and fishing pressure, can affect the growth of grouper. In addition, the difference of growth rates $(\mathrm{k})$ value in one species is also caused by the difference in growth size. [11], [22] and [23] added that differences influence the coefficient growth in location, the method used, environment conditions, the length of maximum fish, and the number of samples. The $\mathrm{k}$ value of the yellow-edged lyretail $<1$ indicates that this fish is growing slowly [20] and has a relatively long life [10]

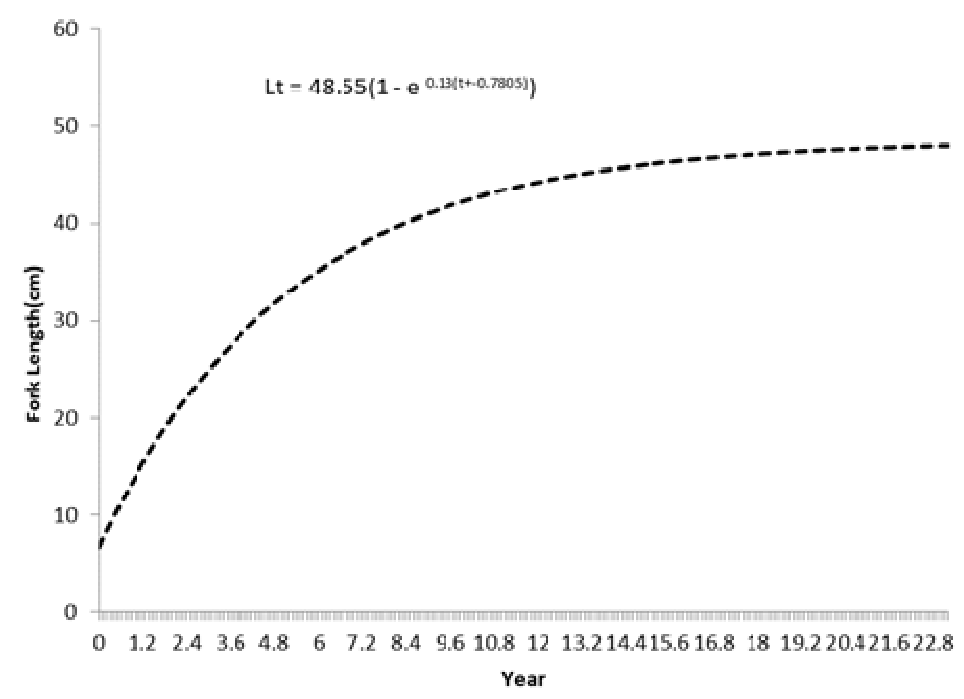

Fig. 4. Growth of the yellow-edged lyretail (Variola louti)

\subsection{The length at first captured $\left(L_{c}\right)$}

The size of the first fish caught or length at first capture (Lc) is $50 \%$ retained fraction (fish caught) from fishing gear. Fish with sizes below Lc will pass from fishing activities and develop to a larger size [24]. The length at first capture for the Variola louti was estimated as $\mathrm{Lc}=31.99 \mathrm{~cm}$. This length was larger than in the Saleh Bay, $\mathrm{Lc}=25.16 \mathrm{~cm}$ [25] 


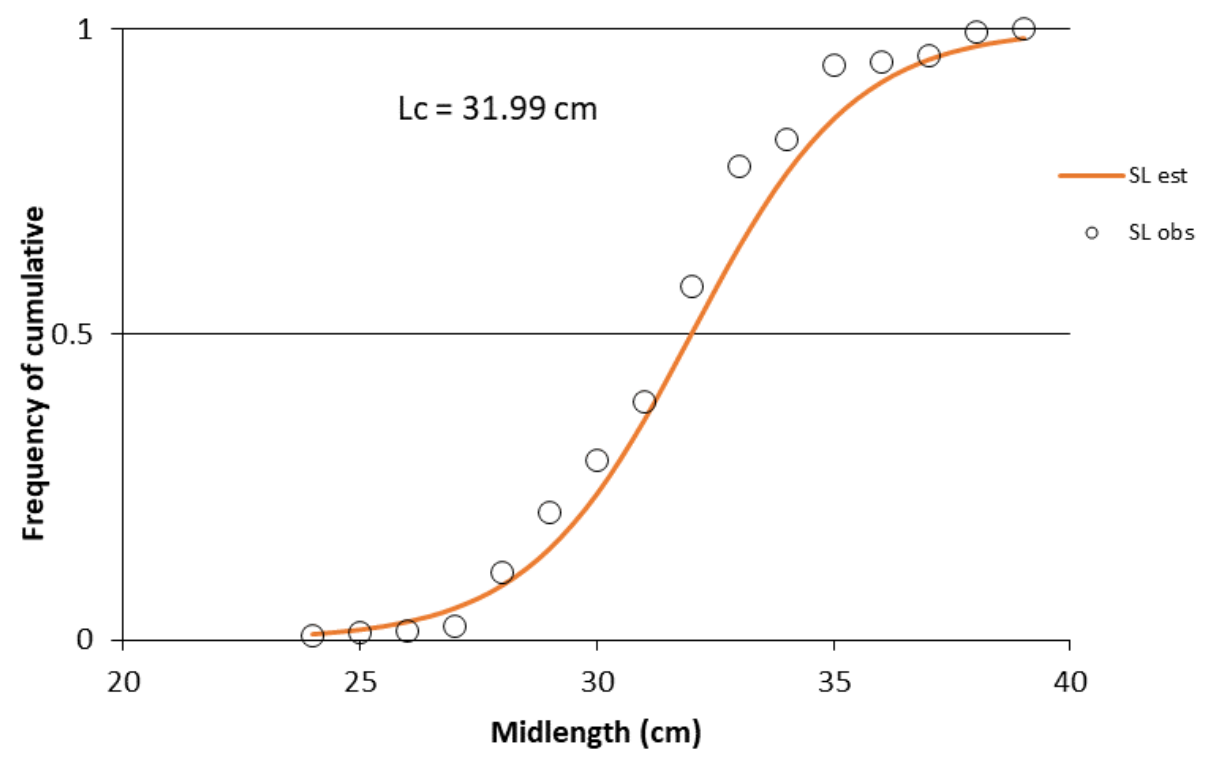

Fig. 5. The length at first capture of the yellow-edged lyretail (Variola louti)

\subsection{The mortality}

The value of natural mortality $(\mathrm{M})$ of Variola louti $=0.42 /$ year, fishing mortality $(\mathrm{F})=$ 0.50 year $^{-1}$, and total mortality $(\mathrm{Z})=0.92$ year $^{-1}$. The exploitation rate $(\mathrm{E})=0.55$ year $^{-1}$. It means exploitation rate has reached optimum (Figure 6).

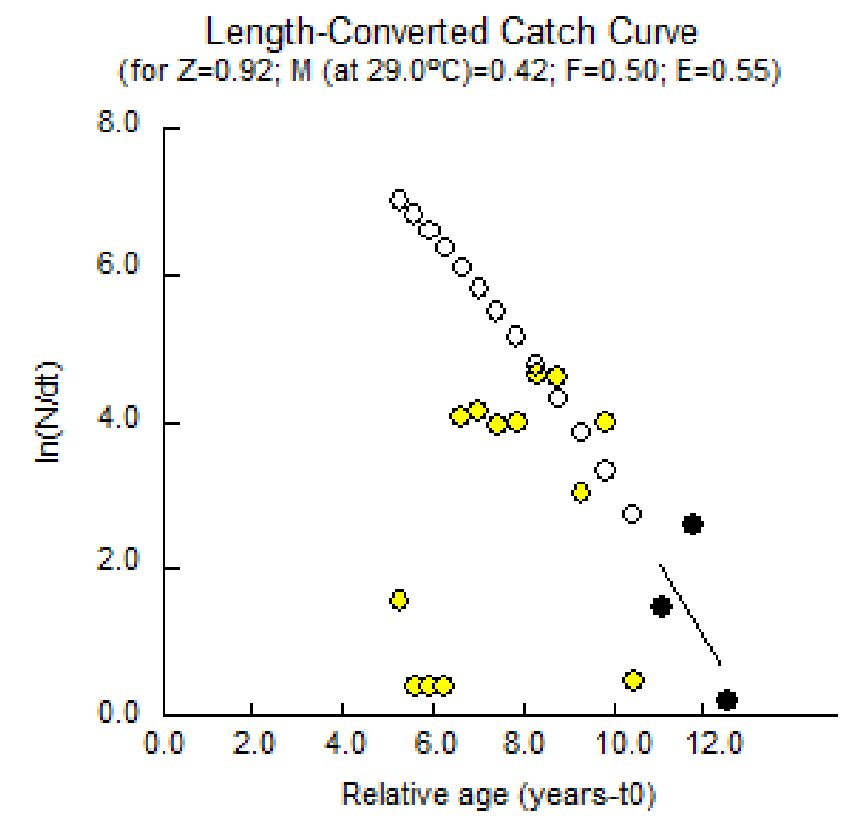

Fig. 6. Catch curve of the yellow-edged lyretail (Variola louti) 
According to [8] and [26] the $\mathrm{M}$ value was affected by the average temperature of water and growth rate $(\mathrm{k})$. The M-value of this grouper at Sibolga was relatively low. This condition, being influenced by the growth value of this fish, was small (Sparre et al.1999). According to [24] classification, which declared that the $M$ value which is classified as high ranged from 1.5 to 2.5 , this is following the statement of [27] The fishing mortality $(0.50)$ is more than natural mortality $(0.42)$, which indicates biological overfishing is occurring. Biological overfishing occurs when fishing mortality reaches a level where biomass in the stock has a negative marginal growth or slows biomass growth [28]. [20] stated that the optimal exploitation rate was when $\mathrm{E}=0.5$. This condition explained that the yellow-edged lyretail fisheries in the Sibolga area were currently optimum $(E>0.5)$. The management measure for this fishery is not to increase the catch effort (vessel units, trips) and still use a precautionary approach to the harvest

\subsection{Recruitment}

The recruitment pattern of the yellow-edged lyretail is presented in Figure 7-the species experience two peak recruitment times in one year. The model on the recruitment chart shows individual additions new to the fish population. The addition can be an individual due to reproduction or increase due to migration from other places. Some groupers have a similar pattern, such as Plectropomus areolatus, P. laevis, P. leopardus, P. maculatus, dan $P$. oligacanthusin Karimunjawa [29]. The recruitment pattern of the yellow-edged lyretail in Sibolga was partial spawning. [30] stated that partial peak recruitment was common in tropical fish species. The peak recruitment of Variola louti was thought to occur in July and October. This period is assumed to be the spawning period of the grouper, resulting in numerous new individuals entering the water.

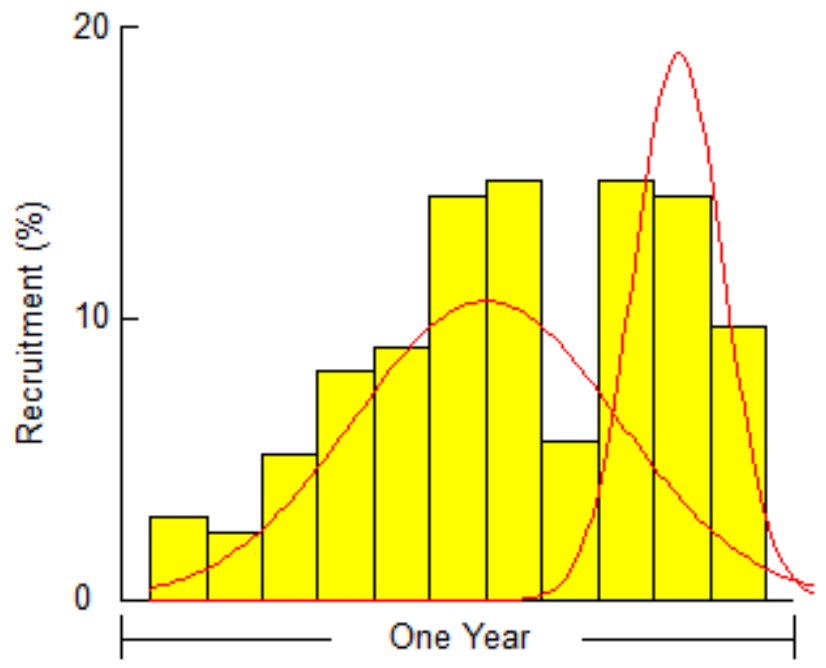

Fig. 7. Recruitment pattern of yellow-edged lyretail (Variola louti) 


\section{Conclusions}

Yellow-edged lyretail (Variola louti) caught in Sibolga waters ranged from 24 to $41 \mathrm{~cm}$ TL (average length $=31.57 \mathrm{~cm}$ ). The length at first capture Lc was $31.99 \mathrm{~cm}$. This fish showed an allometric negative growth pattern. The growth equation $\mathrm{Lt}=48.55\left(1-\mathrm{e}^{0.1}(\mathrm{t}-0.7806)\right)$. The natural mortality $(\mathrm{M})$ value $=0.42$ year- 1 , fishing mortality $(\mathrm{F})=0.50$ year- 1 , total mortality $(Z)=0.92$ year-1 and the exploitation rate $(E)=0,55$ year- 1 .

\section{Acknowledgement}

The authors thank enumerators at Sibolga. This research was funded by the Center for Fisheries Research (CFR) -MMAF.

\section{References}

1. IUCN/GWSG, Final report on workshop for global red list assessment of groupers from Serranidae subfamily Epinephelinae (2007)

2. Hemstra, Randall, FAO species catalog, 16 (1993)

3. Y. Sadovy, Proc. Fourth Asian. Fisheries Forum, China Ocean Press, 321-324 (1997)

4. P. Opic, F. Conand, P. Bourret, Poissons commerciaux du sud-ouest de l'océan Indien (ORSTOM Éditions, Paris, 1994)

5. E.J Sipahutar, A.Rizal, A.A.H.Suryana, A. Nurhayati, J. Penelitian Terapan Perikanan dan Kelaut. 2, 2 (2020)

6. Badan Pusat Statistik, Sibolga city in figures 2018 (in Bahasa Indonesia) (BPS Kab. Sibolga, Sibolga, 2018)

7. P. Sparre, S.C. Venema, Introduction to tropical fish stock assessment (in Bahasa Indonesia) (FAO \& Pusat Penelitian dan Pengembangan Perikanan, Jakarta, 1999)

8. D. Pauly, FAO Fish. Tech. Pap. 243, 52 (1984)

9. D. Pauly, FAO Fisheries Tech. Pap. 234 (1983)

10. D. Pauly, FAO Fish. Circ. FIRM/C729 (1980)

11. M. I. Wahbeh, Pure Sci. 2, 2 (2005)

12. K.T. Kamikawa1, E. Cruz, T.E. Essington, J. Hospital, J.K.T. Brodziak, T.A. Branch, J. Appl. Ichthyol. 31, 1171-1174 (2014)

13. K.D. Carlander, Handbook of freshwater fishery biology Vol. 1 (Iowa State Pr, Iowa, 1969)

14. J.D. Reynolds, S. Jennings, N.K. Dulvy, Life histories of fishes and population responses to exploitation (Conservation Biology Series, Cambridge, 2001)

15. T. Bagenal, A. Tesch. Conditions and growth patterns in fresh water habitats (Blackwel 1 Scientific publications, Oxford, 1987)

16. R. Froese, Cube law, J. of App. Ichthyol. 22 (2006)

17. W.E. Ricker, Growth rates and models (Academic Press, New York, 1979)

18. E.M. Grandcourt, Seychelles Atoll Res. Bul. 539, 201216 (2005)

19. M.R. Heupel, A.J. Williams, D.J. Welch, C.R. Davies, A. Penny, J.P. Kritzer, B. Mapstone, Fish. Bull. 108, 420- 432 (2010) 
20. J.A. Gulland, Fish Stock Assessment: A manual of basic methods: Chichester, U.K. Wiley Interscience, FAO/Wiley Series of Food and Agriculture Vol. 1 (FAO, Chichester, 1983)

21. M. Watson, R.F.G. Ormond, Mar. Ecol. Prog. Ser. 109, 15-29 (1994)

22. J.N. Araùjo, A.S. Martins, J. of the Marine Biological Association of the UK, 86, 187191 (2006)

23. O. Tariche, J.G. Pajuelo, J.M. Lorenzo, A. Luque, J.A. Gonzalez, J. of the Marine Biological Association of the UK, 1-11 (2015)

24. R.J.H. Beverton, S.J. Holt, Ciba Foundation Colloquia on Ageing 5, 142180 (1959)

25. D.S. Efendi, L. Adrianto, Yonvitner, Y. Wardiatno, ISASRM IOP Conf. Ser. Earth Environ. Sci. 744 (2021)

26. M.J. Catalano, M.S. Allen, Fish. Res. 105, 38-45 (2010)

27. P. C. Heemstra, J.E. Randal. FAO Species catalogue. Vol 16. grouper of the world. (Family Serranidae, Subfamily Epinephelinae). An annoted and illustrated catalogue of the grouper and lyretail species known to date (FAO Fisheries Synopsis, Roma, (2005)

28. G.A. Salilew, JMCAR. 3, 1 (2016)

29. S. Agustina, M. Natsir, M. Boer, Purwanto, I. Yulianto, Mar. Fish. 9, 2 (2018).

30. D. Pauly, Conf. Proc. ICLARM, 33-70 (1982) 